\title{
The Maturation of Canada's Retirement Income System: Income Levels, Income Inequality and Low-Income among the Elderly
}

\author{
by \\ John Myles \\ 11F0019MPE No. 147 \\ ISSN: 1200-5223 \\ ISBN: 0-660-18092 \\ Statistics Canada \\ and \\ Florida State University \\ E-mail: jmyles@coss.fsu.edu
}

March 6, 2000

Thanks to Bob Baldwin, Karen Maser and Leroy Stone for their comments on a previous draft of this paper. This paper represents the views of the author and does not necessarily reflect the opinions of Statistics Canada. 



\section{Table of Contents}

1. Introduction _ 1

2. Data and Methods__ 3

3. Trends in Income Levels ___ 6

4. Trends in Inequality___ 9

5. Low (and High) Income Trends __ 15

6. Conclusion__ 19

References__ 20 



\begin{abstract}
I revisit trends in the level and distribution of income among Canadian seniors in the context of what is arguably the major source of change in these trends since the end of the seventies, the maturation of Canada's public pension systems and the continued development of private pension systems. The expanded role of pensions in the 1980s and 1990s is largely the result of changes that occurred in the 1950s and 1960s. The Canada and Quebec Pension Plans (C/QPP) were implemented in 1966 and the first cohort to receive full C/QPP benefits turned 65 in 1976. Cohorts retiring after this period were also the beneficiaries of the expansion of private occupational pensions that took place between the 1950s and the 1970s. I rely on a detailed decomposition of income by source to show that not only did the maturation of these earningsrelated programs (public and private pensions) produce a substantial increase in average real incomes but also to a substantial reduction in income inequality among the elderly, due mainly to C/QPP benefits. Rising real incomes went disproportionately to lower income seniors contributing to the well-known decline in low-income rates among the elderly.
\end{abstract}

Keywords: retirement income, pension, inequality, low-income 



\section{Introduction}

Since the early 1980s, virtually every OECD nation has undergone at least one major pension reform and the process of change is far from over. ${ }^{1}$ The pressures for reform are well known. Rapidly aging populations combined with slow economic growth have created an atmosphere of austerity very different from the expansionary years from the fifties through the seventies when most contemporary old age security systems were designed. And unlike the 1960s when there was broad consensus in most countries that the elderly were "too poor," claims that the elderly have perhaps become "too rich" (relative to other groups) have been heard in some countries.

Against this international backdrop, Canada's old age security system appears to have achieved an enviable position. Canadian public expenditures on income security for seniors are modest by international standards and are projected to peak at levels well below those anticipated by most other Western nations in the next century (Organization for Economic Cooperation and Development, 1997). ${ }^{2}$ Nevertheless, low-income rates among Canadian seniors measured by the usual "relative" international standard (persons with adjusted incomes less than 50 percent of the median) are now among the lowest in the OECD, even when compared to egalitarian Sweden (Hauser, 1997; Smeeding and Sullivan, 1998). ${ }^{3}$ Moreover, as I show below, this development is not an artifact of simply moving large numbers of seniors from just below to just above the usual low-income cut-offs. The income gains among lower-income seniors have been substantial. Conversely, it would be extremely difficult to make a case for the claim that Canadian seniors have become "too rich." Mean incomes among the Canadian elderly have risen substantially since the early 1980s but virtually all of the gains have taken place at the lower end of the income distribution.

These outcomes represent a remarkable turnaround from a few decades ago when Canadian seniors fared poorly by international and even by U.S. standards. ${ }^{4} \mathrm{My}$ aim in this paper is to describe the process of income formation that has driven these developments and what is arguably the main change in Canada's retirement income system over the period, the maturation of Canada's public pension system and the continued development of private plans. Between 1980 and 1996, income from contributory public and private earnings-related pensions rose from approximately 21 to 46 percent of disposable income among the population $65+$. The share of

1 For a review and analysis of these reforms see Myles and Pierson (In Press).

2 The OECD (1997) projects that Canadian expenditures on public pensions will rise to 9.1 percent of GDP in 2040 from 5.2 percent in 1995. By way of contrast, average expenditures in the continental European countries were 10 percent of GDP in 1995 and projected to rise to 16 percent in 2040 (see Myles and Pierson, in press).

3 By the usual international standard, low-income rates among Canadian seniors had fallen to about 5 percent in 1994 compared to a U.S. rate in excess of 20 percent. And among the population 70+, Canada's low-income rate was below that of Sweden the usual "winner" in the international league tables on poverty reduction (Smeeding and Sullivan, 1998).

4 In the mid-seventies low-income rates among Canadian seniors were still well above those of their American peers (Myles and Quadagno, 1994; Smeeding and Sullivan, 1998). And the first truly comparative studies of low-income rates among seniors for the early 1980s placed Canada at the lower end of the international league tables (Smeeding, Torrey and Martin, 1986). 
income from Old Age Security (OAS) and the income-tested Guaranteed Income Supplement (GIS), in contrast, remained stable in the 1980s and declined slightly in the 1990s.

The expanded role of earnings-related pensions in the 1980s and 1990s is the result of changes that occurred in the 1950s and 1960s. The Canada and Quebec Pension Plans (C/QPP) were implemented in 1966 and the first cohort to receive full C/QPP benefits turned 65 in 1976 . The rising importance of C/QPP income since then is a result of cohort succession among the elderly as more recent cohorts displace older cohorts and by a dramatic increase in the share of women receiving their own C/QPP pension. ${ }^{5}$ Private occupational pensions grew rapidly in the 1950 s and 1960s reaching a coverage rate for paid workers of 40 percent in 1970. Cohorts retiring as late as 1980 were unlikely to have significant contribution years (they entered the labour market in the 1930s and 1940s) but the average number of contribution years and coverage rates were rising among successive retirement cohorts as the decade proceeded, a trend noted over a decade ago by Oja and Love (1988).

Earnings-related pensions are not the usual policy instruments one thinks of when considering reducing income inequality or low-income rates among seniors. They are aimed, after all, at reproducing the income differentials created during the working years. Since a large share of benefits in all such plans goes to middle and upper income families, it is often argued that the social insurance (i.e. earnings-related) model creates welfare states for the middle class that do little to help the poor or achieve more equality (Le Grand, 1982; Mitchell, Harding, and Gruen, 1994). The implicit, equality-generating, counterfactual in these arguments are benefit systems dominated by flat-benefit programs (such as Old Age Security) that deliver uniform benefits to all irrespective of past earnings and/or income-tested programs (such as the Guaranteed Income Supplement) that provide benefits that are inversely related to other sources of income (and implicitly to past earnings and savings).

At least since Titmuss (1955), however, many policy analysts have argued that the addition of mandatory earnings-related plans like C/QPP to "basic security" programs (such as OAS/GIS) reduce income inequality. The classic argument supporting this thesis rests on assumptions concerning the "second-order" effects of a public pension system on the political behavior of both voters and policy-makers. Since targeted or even flat benefit programs disproportionately benefit the poor, it is argued, they do not generate the political coalitions (requiring the support of middle income earners) necessary to sustain them in the long run. Consequently, as Titmuss (1955), and others since, have argued the creation of earnings-related pensions may be necessary to reduce income inequality a phenomenon that has become known as the "paradox of redistribution" (Korpi and Palme, 1998; Pedersen, 1999).

The "paradox" formulation rests on an assumption of uneven development of firm-based occupational plans and individual retirement savings that inevitably produce more heterogeneous outcomes among workers with otherwise identical earnings records and work histories. ${ }^{6}$

5 Married persons in families receiving at least one C/QPP pension rose from 74 to 93 percent between 1980 and 1996 and the percent in families receiving two C/QPP pensions from 18 to 55 percent. Sixty-five percent of couples also received at least one private pension by 1996, up from 45 percent in 1980. The percent of unattached elderly women receiving a C/QPP benefit rose from 44 to 78 percent over the period and 39 percent were receiving a private pension in 1996, up from 29 percent in 1980.

6 For a detailed discussion see Pedersen (1999).

Analytical Studies Branch - Research Paper Series

$-2-$

Statistics Canada No. 11F0019MPE No. 147 
Mandatory systems such as the C/QPP offset the lower propensity of low wage-earners to save for retirement (Diamond and Hausman, 1984), on the one hand, and on the other, the fact that low-wage workers who are not unionized are unlikely to be covered by private plans (Blinder, 1983).

While there is considerable prima facie evidence in favour of this thesis (see Korpi and Palme, 1998), constructing the behavioural models required to test for these "second-order" effects of alternative policy development is at least as empirically intractable as the more familiar problem of constructing behavioural models to test claims about the impact of social expenditures on work incentives and savings behaviour (Pedersen, 1999). In short, there is no way of measuring the counterfactual: what would have happened to the incomes of seniors had, OAS/GIS, the C/QPP and employer pensions not been established or developed in a different mix. ${ }^{7}$ My aim here is decidedly more modest, to describe what has actually happened to the level and distribution of incomes among Canadian seniors since 1980 as the C/QPP and private pension systems have been maturing. The descriptive results are nonetheless instructive and raise an additional set of issues.

Over the 1980s, rising incomes among the elderly were dominated by rising C/QPP benefits and, as I show, the results clearly reduced income inequality. Over most of the income distribution (the second through fifth quintiles) C/QPP benefits were uniformly distributed. These results, however, describe a particular moment in history and it is unlikely that trends through the end of this decade and into the next will resemble those of the 1980s and early 1990s. The C/QPP was "rushed" to maturity by legislation that provided full benefits after only 10 years of contributions. The full impact of expanded coverage and rising benefits from employer plans (RRPs) and personal retirement accounts (RRSPs) will take longer to appear. I return to these issues in the discussion.

The paper is organized as follows. Section 2 discusses data sources and methodological issues. In section 3, I briefly consider changes in mean incomes by income source. Section 4 , the core of the paper, describes the changing distribution of old age incomes (inequality). In section 5, I briefly revisit trends in low-income rates among seniors.

\section{Data and Methods}

The underlying data on which the analysis is based are from the Survey of Consumer Finances economic family file for two years at the beginning of the 1980s $(1980,1981)$, one year in the middle of the decade (1986) and all years from 1988 through 1996. As with younger cohorts, however, interpolating secular trends in the level and distribution of income among the elderly

7 Thus, more recent retirees have had much higher lifetime earnings than earlier cohorts with greater opportunities to save for their old age so that some (unknown) increase in average old age incomes was to be expected regardless of expanding pension entitlements. Similarly, while personal retirement savings are highly concentrated among upper income seniors, this is at least in part the result of behavioural response to the presence of programs like C/QPP. In the absence of C/QPP, it is quite likely that lower income seniors today would be receiving a larger share of private pension income. Whereas behavioural response to income support plans such as social assistance among working-age adults is often assumed to be modest, "behavioural response" to the presence of significant public pension schemes, including those that are not earnings-related, must be assumed to be very large indeed. 
requires careful consideration of cyclical effects associated with the business cycle. Among working-age families the main concern is with identifying points in the cycle when employment and unemployment levels are approximately the same. Among seniors, the main confounding cyclical factor is associated with trends in interest rates, which have a profound impact on investment income (Chart 1). Investment income was high both at the beginning and at the end of the 1980s, when real interest rates were at their peak, and has declined since the early 1990s as interest rates have fallen. To identify secular trends, therefore, much of the analysis will focus on years in which interest rates were roughly similar. The years 1980 (prime rate $=14.25$ ) and 1990 (prime rate $=14.06$ ) are two points that are comparable. The closest approximation for the later period are the years 1991 and 1995 when the prime rate stood at 9.94 and 8.65, respectively.

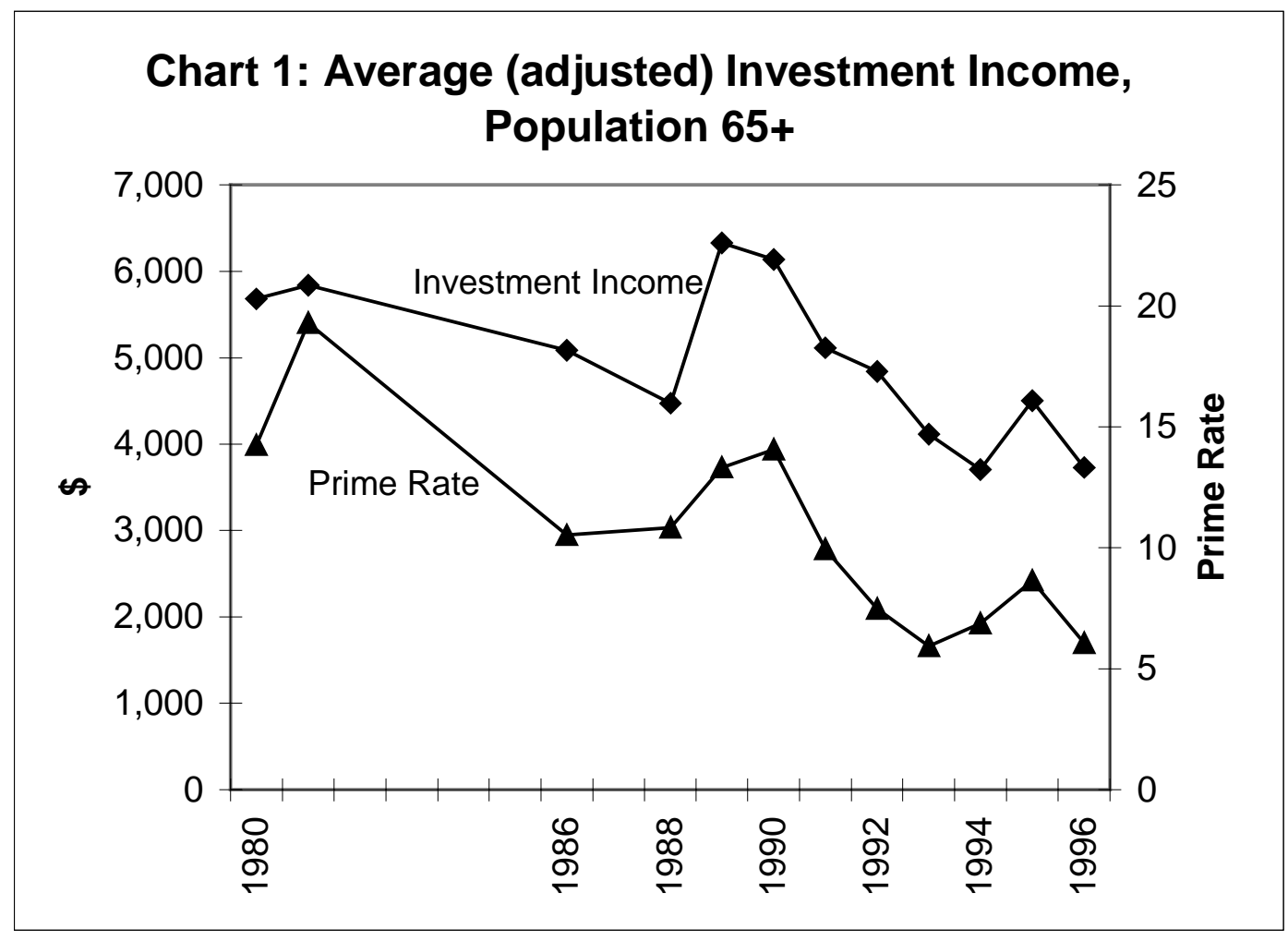

The income units and adjustments to income reflect standard practise in studies of economic well being (Atkinson, Rainwater, and Smeeding, 1995). As with the calculation of Statistics Canada's Low-Income Cut-Offs, income is assessed on the basis of the economic family which includes all individuals sharing a common dwelling and related by blood, marriage and adoption. The unit of analysis, however, is the individual and I include all persons who were age 65 or greater in the reference years. If we counted families (or households) rather than individuals this would implicitly give persons in larger households smaller weights than persons living on their own (Hauser, 1997: 2) and the aim is to give equal importance to the well-being of each person irrespective of their living arrangements.

To compute individual incomes, a per capita income is calculated. Rather than divide family income by family size, however, I make use of an equivalence scale to take account of economies of scale. Results can be highly sensitive to the choice of equivalence scales (Burkhauser, Smeeding, and Merz, 1996). In the present study, the main impact of the choice of equivalence 
scale is on the estimated differences between seniors living on their own (e.g. unattached elderly women) and elderly married couples and other persons living with family members. I have used the "central variant" proposed by Wolfson and Evans (1990: 46-47) which assigns a weight of 1.0 to the first person and 0.4 to each additional person. If one were to assume lower economies of scale (e.g. by assigning a weight of 0.6 or 0.8 to the second person) differences between unattached and other seniors would be smaller than reported here but not, of course, the overall direction of change. The fact that all dollar values presented in the tables and text are "adjusted" dollars should be kept in mind, however, when drawing comparisons with other sources. All dollar values have of course been adjusted for inflation with the CPI and are expressed in 1996 constant dollars.

The choice of the economic family as the income unit also requires some comment since family income includes income received by all family members, including those who are not elderly (e.g. children, siblings or other persons related by blood or marriage). The choice is the appropriate one for an analysis of the economic welfare of the elderly but this is different from an assessment of the economic resources of the elderly, a topic being pursued separately. The assumption is that seniors residing in higher income families enjoy a higher living standard than seniors in lower income families irrespective of the source of that income. The upshot, however, is that results reported here reflect changing living arrangements among the elderly as well as changes in the amount of income received by the elderly themselves from pensions, investments, but especially earnings. The implications of such changes, particularly in the share of seniors residing with another family member who is a labour force participant are reported in footnotes as appropriate. ${ }^{8}$

Much of the analysis reports a single series for all elderly individuals without distinguishing by family type. However, results are sometimes reported separately for unattached (single, widowed and divorced) elderly women living on their own, a sector of the elderly population traditionally seen as among the most economically vulnerable in old age.

For purposes of this analysis, total income is divided among employment income, investment income, income from private pensions, C/QPP income, OAS/GIS income, other government transfers and income taxes paid. Since 1989, OAS benefits have been "clawed back" from highincome seniors. 9 The "clawback" is counted among taxes paid.

Investment income includes dividends, interest, rental and estate income. Private pension income includes retirement pensions, annuities and superannuation. Ideally, I would treat income from personal retirement accounts (RRIF income) separately from income from employer pensions.

8 Rising pension income may effect family earnings among the elderly in two ways: a) by reducing the labour supply of older persons; b) by reducing the propensity of elderly persons to reside with other family members (e.g. adult children) who are in the labour force. The share of all elderly persons in the labour force declined from 10.1 percent in 1980 to 6.3 percent in 1995 . The share of all elderly persons who were not in the labour force but residing with a family member who was a labour force participant declined from 19 to 17 percent. The percent of elderly persons in families with no labour force participant present rose from 71 to 77 percent.

9 Out of a total 3,718,017 OAS recipients in 1996, 114,193 (3.1 percent) were subject to the clawback but still received partial OAS benefits, while 61,029 (1.6 percent) were not eligible for OAS because their benefits were fully clawed back. All told, then, 175,222 seniors or 4.7 percent of OAS recipients were subject to the income test (Ken Battle, Caledon Institute, personal communication). 
This is possible since 1993 but not in earlier years so that both kinds of income are included with private pension income.

Table 1: Changes in Mean Adjusted Income by Source, Population 65+ 1980-90 and 1991-95

\begin{tabular}{|c|c|c|c|c|c|c|c|c|}
\hline \multicolumn{10}{|c|}{} & $\begin{array}{c}\text { 1980-1990 } \\
\text { Disposable } \\
\text { Income } \\
\text { (minus taxes) }\end{array}$ & $\begin{array}{c}\text { Employment } \\
\text { Income }\end{array}$ & $\begin{array}{c}\text { Private } \\
\text { Pensions }\end{array}$ & $\begin{array}{c}\text { Investment } \\
\text { Income }\end{array}$ & OAS/GIS & C/QPP & $\begin{array}{c}\text { Other } \\
\text { Transfers }\end{array}$ & Taxes \\
\hline 1980 & 20,735 & 6,109 & 2,649 & 5,682 & 5,944 & 1,696 & 761 & 2,106 \\
\hline 1990 & 22,872 & 4,454 & 4,333 & 6,135 & 6,562 & 3,717 & 1,027 & 3,355 \\
\hline Change & $\mathbf{2 , 1 3 7}$ & $\mathbf{- 1 , 6 5 5}$ & $\mathbf{1 , 6 8 4}$ & $\mathbf{4 5 3}$ & $\mathbf{6 1 8}$ & $\mathbf{2 , 0 2 1}$ & $\mathbf{2 6 6}$ & $\mathbf{1 , 2 4 9}$ \\
\hline \% change & $\mathbf{1 0 \%}$ & $\mathbf{- 2 7 \%}$ & $\mathbf{6 4 \%}$ & $\mathbf{8 \%}$ & $\mathbf{1 0 \%}$ & $\mathbf{1 1 9 \%}$ & $\mathbf{3 5 \%}$ & $\mathbf{5 9 \%}$ \\
\hline \multicolumn{7}{|c|}{ Percentage Distribution by Source } \\
\hline 1980 & $100 \%$ & $29.5 \%$ & $12.8 \%$ & $27.4 \%$ & $28.7 \%$ & $8.2 \%$ & $3.7 \%$ & $10.2 \%$ \\
\hline 1990 & $100 \%$ & $19.5 \%$ & $18.9 \%$ & $26.8 \%$ & $28.7 \%$ & $16.3 \%$ & $4.5 \%$ & $14.7 \%$ \\
\hline Change & \multicolumn{10}{|c|}{$10.0 \%$} & $\mathbf{6 . 2 \%}$ & $\mathbf{- 0 . 6 \%}$ & $\mathbf{0 . 0 \%}$ & $\mathbf{8 . 1 \%}$ & $\mathbf{0 . 8 \%}$ & $\mathbf{4 . 5 \%}$ \\
\hline
\end{tabular}

\begin{tabular}{|c|c|c|c|c|c|c|c|c|}
\hline \multicolumn{1}{|c|}{} & $\begin{array}{c}\text { Disposable } \\
\text { Income } \\
\text { (minus taxes) }\end{array}$ & $\begin{array}{c}\text { Employment } \\
\text { Income }\end{array}$ & $\begin{array}{c}\text { Private } \\
\text { Pensions }\end{array}$ & $\begin{array}{c}\text { Investment } \\
\text { Income }\end{array}$ & OAS/GIS & C/QPP & $\begin{array}{c}\text { Other } \\
\text { Transfers }\end{array}$ & Taxes \\
\hline 1991 & 22,305 & 5,065 & 4,247 & 5,117 & 6,542 & 3,674 & 1,082 & 3,421 \\
\hline 1995 & 23,082 & 4,581 & 5,656 & 4,503 & 6,332 & 4,525 & 1,100 & 3,616 \\
\hline Change & $\mathbf{7 7 7}$ & $\mathbf{- 4 8 4}$ & $\mathbf{1 , 4 0 9}$ & $\mathbf{- 6 1 4}$ & $\mathbf{- 2 1 0}$ & $\mathbf{8 5 1}$ & $\mathbf{1 8}$ & $\mathbf{1 9 5}$ \\
\hline \% change & $\mathbf{3 \%}$ & $\mathbf{- 1 0 \%}$ & $\mathbf{3 3 \%}$ & $\mathbf{- 1 2 \%}$ & $\mathbf{- 3 \%}$ & $\mathbf{2 3 \%}$ & $\mathbf{2 \%}$ & $\mathbf{6 \%}$ \\
\hline \multicolumn{7}{|c|}{} \\
\hline 1991 & $100 \%$ & $22.7 \%$ & $19.0 \%$ & $22.9 \%$ & $29.3 \%$ & $16.5 \%$ & $4.9 \%$ & $15.3 \%$ \\
\hline 1995 & $100 \%$ & $19.8 \%$ & $24.5 \%$ & $19.5 \%$ & $27.4 \%$ & $19.6 \%$ & $4.8 \%$ & $15.7 \%$ \\
\hline Change & \multicolumn{2}{|c|}{ Percentage Distribution by Source } \\
\hline
\end{tabular}

\section{Trends in Income Levels}

Mean disposable (after tax) incomes among the elderly rose during the 1980s and were roughly at the same level in 1996 as in 1989 (Chart 2). Over the time intervals (1980-1990 and 1991-1995) identified earlier as appropriate for comparison, mean disposable income rose $10 \%$ and $3 \%$ respectively (Table 1).

The increase in average incomes reflected sharp increases in pension incomes that more than offset declining employment incomes and rising taxes. Together, C/QPP and private pension income rose from $21 \%$ of disposable income in 1980 to $45 \%$ in 1995 . The largest gains were from C/QPP income (\$2021) in the 1980s and from private pensions (\$1409) in the 1990s. Over the entire period (1980-95), the share of private pension income doubled (from 13\% to $25 \%$ ) while C/QPP income more than doubled (from 8\% to almost 20\%). As suggested in the introduction, the larger increase in private pensions evident in the 1990s reflects a development that will undoubtedly continue in future. 
OAS/GIS income rose in the 1980s (+\$618) and then declined slightly (-\$210) in the 1990s. The OAS/GIS share of disposable income fell slightly from approximately $29 \%$ in 1980 to $27 \%$ in 1995. The changes reflect two offsetting trends: an increase in GIS benefits in 1984; and the fact that as income from other sources (e.g. pension income) rises, GIS benefits for low-income seniors falls (at the rate of 50 cents for each dollar of additional income from other sources).

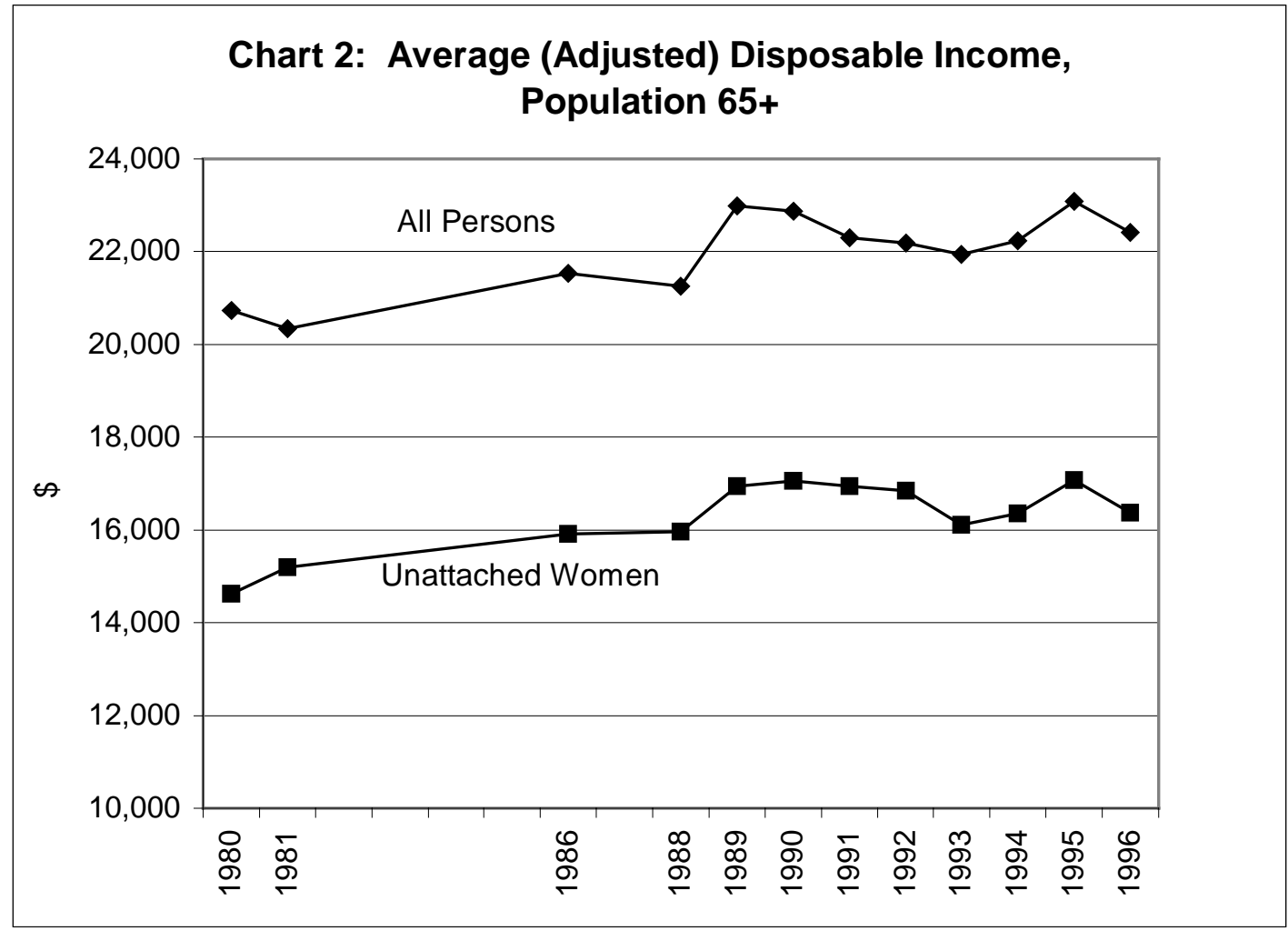

Investment income was slightly higher $(+\$ 453)$ in 1990 than in 1980 but was substantially lower by 1995 reflecting some unknown mix of the impact of changing interest rates (Chart 1) and possible substitution of pensions for other forms of savings. One obvious implication of the growing importance of earnings-related pension income relative to other forms of saving is the much lower volatility of the former compared to the latter and, as a result, greater income security for seniors.

The share of employment income fell from about 30 to 20 percent of disposable income during the 1980s and remained at that level in the 1990s. ${ }^{10}$ Income taxes rose from about 10 percent of total income in 1980 to almost 16 percent by 1995, reflecting both the rising incomes of seniors and changing tax provisions (including the OAS “clawback" implemented in 1989).

10 About one third of the decline in earnings could be explained by changes in the living arrangements of elderly persons, that is by change in the proportion of elderly persons residing with another family member who is a labour force participant. This is a maximum estimate since it takes account of compositional shifts only and does not include any behavioural response by the elderly persons or changes in behaviour on the part of other family members (e.g. younger spouses or older adult children) who might also reduce their labour supply in response to the higher pension income of the elderly person. Strikingly, among all retired persons over 65 residing with other family members still in the labour force, pension income was the only source of rising family incomes over the 1980-95 period. Total pension income in these families rose from 25 to 38 percent of disposable income as a result. 


\section{Unattached Elderly Women}

"Unattached" women (widowed, divorced and single women living on their own) have long been among the more vulnerable members of the elderly population. Average incomes in this population grew somewhat more (17\%) between 1980 and 1995 than among all seniors (11\%).

Table 2: Changes in Mean Adjusted Income by Source, Unattached Women 65+ 1980-90 and 1991-95

\begin{tabular}{|c|c|c|c|c|c|c|c|c|}
\hline \multicolumn{9}{|c|}{ 1980-1990 } \\
\hline & $\begin{array}{c}\text { Disposable } \\
\text { Income } \\
\text { (minus taxes) }\end{array}$ & $\begin{array}{c}\text { Employment } \\
\text { Income }\end{array}$ & $\begin{array}{c}\text { Private } \\
\text { Pensions }\end{array}$ & $\begin{array}{l}\text { Investment } \\
\text { Income }\end{array}$ & $\begin{array}{c}\text { OAS/ } \\
\text { GIS }\end{array}$ & C/QPP & $\begin{array}{c}\text { Other } \\
\text { Transfers }\end{array}$ & Taxes \\
\hline 1980 & 14,630 & 975 & 1,693 & 4,820 & 6,151 & 1,231 & 531 & 772 \\
\hline 1990 & 17,061 & 603 & 2,423 & 5,126 & 7,040 & 2,753 & 913 & 1,797 \\
\hline Change & 2,431 & -372 & 730 & 306 & 889 & 1,522 & 382 & $\mathbf{1 , 0 2 5}$ \\
\hline$\%$ change & $17 \%$ & $-38 \%$ & $43 \%$ & $6 \%$ & $14 \%$ & $124 \%$ & $72 \%$ & $133 \%$ \\
\hline \multicolumn{9}{|c|}{ Percentage Distribution by Source } \\
\hline 1980 & $100 \%$ & $7 \%$ & $12 \%$ & $33 \%$ & $42 \%$ & $8 \%$ & $4 \%$ & $5 \%$ \\
\hline 1990 & $100 \%$ & $4 \%$ & $14 \%$ & $30 \%$ & $41 \%$ & $16 \%$ & $5 \%$ & $11 \%$ \\
\hline Change & & $-3.1 \%$ & $2.6 \%$ & $-2.9 \%$ & $-0.8 \%$ & $7.7 \%$ & $1.7 \%$ & $5.3 \%$ \\
\hline
\end{tabular}

\begin{tabular}{|c|c|c|c|c|c|c|c|c|}
\hline \multicolumn{1}{|c|}{$\begin{array}{c}\text { 1991-1995 } \\
\text { Income } \\
\text { (minus taxes) }\end{array}$} & $\begin{array}{c}\text { Employment } \\
\text { Income }\end{array}$ & $\begin{array}{c}\text { Private } \\
\text { Pensions }\end{array}$ & $\begin{array}{c}\text { Investment } \\
\text { Income }\end{array}$ & $\begin{array}{c}\text { OAS/ } \\
\text { GIS }\end{array}$ & C/QPP & $\begin{array}{c}\text { Other } \\
\text { Transfers }\end{array}$ & Taxes \\
\hline 1991 & 16,936 & 507 & 2,666 & 4,795 & 6,950 & 2,924 & 933 & 1,840 \\
\hline 1995 & 17,081 & 516 & 3,749 & 3,273 & 6,770 & 3,875 & 853 & 1,956 \\
\hline Change & $\mathbf{1 4 5}$ & $\mathbf{9}$ & $\mathbf{1 , 0 8 3}$ & $\mathbf{- 1 , 5 2 2}$ & $\mathbf{- 1 8 0}$ & $\mathbf{9 5 1}$ & $\mathbf{- 8 0}$ & $\mathbf{1 1 6}$ \\
\hline \% change & $\mathbf{1 \%}$ & $\mathbf{2 \%}$ & $\mathbf{4 1 \%}$ & $\mathbf{- 3 2 \%}$ & $\mathbf{- 3 \%}$ & $\mathbf{3 3 \%}$ & $\mathbf{- 9 \%}$ & $\mathbf{6 \%}$ \\
\hline \multicolumn{7}{|c|}{} \\
\hline 1991 & $100 \%$ & $3 \%$ & $16 \%$ & $28 \%$ & $41 \%$ & $17 \%$ & $6 \%$ & $11 \%$ \\
\hline 1995 & $100 \%$ & $3 \%$ & $22 \%$ & $19 \%$ & $40 \%$ & $23 \%$ & $5 \%$ & $11 \%$ \\
\hline Change & \multicolumn{7}{|c|}{ Percentage Distribution by Source } \\
\hline
\end{tabular}

Strikingly, C/QPP benefits played the dominant role in this increase. C/QPP income rose from 8 to 16 percent of total income between 1980 and 1990 and to 23 percent in 1995. Private pension grew from 12 to 22 percent of total income over the entire period. Among these cohorts of women, one suspects this is mainly a result of survivor benefits.

While trends among unattached elderly women are often used as an indicator of what is happening to the most economically vulnerable seniors, like any other groups they are not an economically homogeneous population. In the following section we examine changes among lower and higher income seniors directly. 


\section{Trends in Inequality}

Income inequality as indexed by the Gini index (Chart 3) declined substantially over the 1980s (from .325 in 1980 to .274 in 1990), stabilizing at a slightly lower level in the mid-nineties (.266 in 1995). Since Gini indices are not readily intuitive numbers, it is instructive to examine the same changes in terms of changing income levels by income quintile (Table 3).

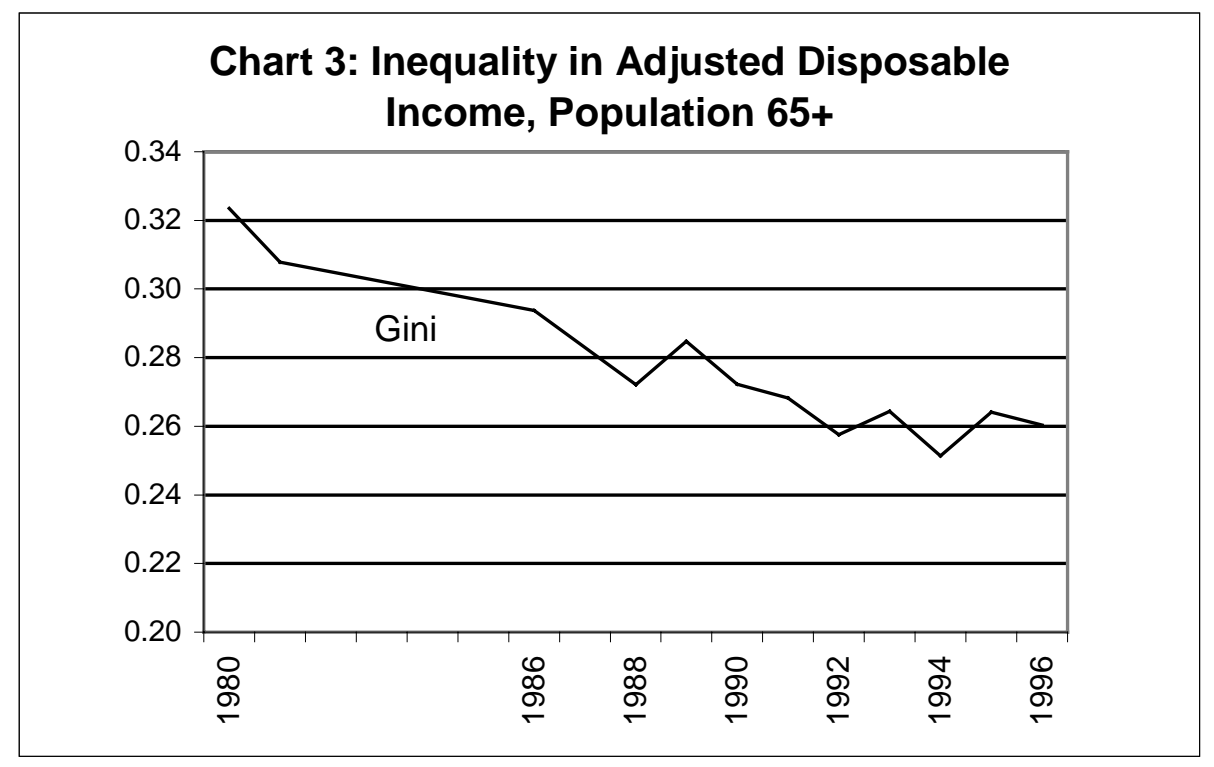

Average incomes rose in all income quintiles during the 1980s but gains were inversely related to income level, rising by $31 \%$ in the lowest quintile, by less than $10 \%$ in the fourth quintile and by only $1 \%$ in the top quintile. Both absolute and relative changes in the 1990s were considerably more modest than in the 1980s.

Table 3: Mean Adjusted Disposable Income by Income Quintile, Population 65+

\begin{tabular}{|c|c|c|c|c|}
\hline & 1980 & 1990 & 1991 & 1995 \\
\hline First & 8,805 & 11,573 & 11,772 & 12,283 \\
\hline Second & 12,485 & 15,188 & 14,992 & 15,546 \\
\hline Third & 16,334 & 19,074 & 18,288 & 19,329 \\
\hline Fourth & 23,672 & 25,812 & 24,581 & 25,326 \\
\hline \multirow[t]{3}{*}{ Fifth } & 42,389 & 42,719 & 41,919 & 42,934 \\
\hline & \multicolumn{2}{|c|}{ 1980-1990 } & \multicolumn{2}{|c|}{$1991-1995$} \\
\hline & Change & \% Change & Change & $\%$ Change \\
\hline First & $\$ \quad 2,768$ & $31 \%$ & $\$ \quad 511$ & $4 \%$ \\
\hline Second & $\$ \quad 2,703$ & $22 \%$ & $\$ 554$ & $4 \%$ \\
\hline Third & $\$ \quad 2,740$ & $17 \%$ & $\$ 1,041$ & $6 \%$ \\
\hline Fourth & $\$ \quad 2,140$ & $9 \%$ & $\$ 745$ & $3 \%$ \\
\hline Fifth & 330 & $1 \%$ & $\$ 1,015$ & $2 \%$ \\
\hline
\end{tabular}


The process of income formation underlying these changes can be read off fairly directly from the corresponding changes in income by source among income quintiles (Tables 4 and 5). In the 1980s, rising incomes in the lowest quintile reflected a substantial increase in OAS/GIS benefits (+\$2000) and C/QPP income (+\$850). In the second through fourth quintiles C/QPP benefits were the largest source of rising incomes and were clearly equalizing. Increases in $\mathrm{C} / \mathrm{QPP}$ benefits in the second through fifth quintiles were little different from a uniform transfer, rising by $\$ 2100$ in the second and third quintiles and by $\$ 2500$ in the fourth and fifth quintiles. Falling employment income in the fourth and fifth quintiles was more than offset by significantly higher private pension and C/QPP income and by higher investment income in the fifth quintile. But these gains were reduced and almost entirely offset in the top quintile by sharply higher taxes (which by 1990 include the "clawback" of OAS benefits).

Table 4: Mean Adjusted Income by Source and Income Quintile, Population 65+, 1980-1990

\begin{tabular}{|cc|c|c|c|c|c|c|c|c|}
\hline QUINTILE & $\begin{array}{c}\text { Disposable } \\
\text { Income } \\
\text { (minus taxes) }\end{array}$ & $\begin{array}{c}\text { Employment } \\
\text { Income }\end{array}$ & $\begin{array}{c}\text { Private } \\
\text { Pensions }\end{array}$ & $\begin{array}{c}\text { Other } \\
\text { Market } \\
\text { Income }\end{array}$ & $\begin{array}{c}\text { OAS/ } \\
\text { GIS }\end{array}$ & $\begin{array}{c}\text { CPP/ } \\
\text { QPP }\end{array}$ & $\begin{array}{c}\text { Other } \\
\text { Transfers }\end{array}$ & Taxes \\
\hline Bottom & 1980 & 8,805 & 124 & 233 & 665 & 6,433 & 666 & 720 & 35 \\
& 1990 & 11,573 & 111 & 217 & 604 & 8,435 & 1,513 & 943 & 250 \\
Change & $\mathbf{2 , 7 6 8}$ & $\mathbf{- 1 3}$ & $\mathbf{- 1 6}$ & $\mathbf{- 6 1}$ & $\mathbf{2 , 0 0 2}$ & $\mathbf{8 4 7}$ & $\mathbf{2 2 3}$ & $\mathbf{2 1 5}$ \\
\hline Second & 1980 & 12,485 & 436 & 684 & 1,764 & 7,432 & 1,362 & 856 & 50 \\
& 1990 & 15,188 & 452 & 996 & 1,955 & 7,686 & 3,452 & 935 & 289 \\
& Change & $\mathbf{2 , 7 0 3}$ & $\mathbf{1 6}$ & $\mathbf{3 1 2}$ & $\mathbf{1 9 1}$ & $\mathbf{2 5 4}$ & $\mathbf{2 , 0 9 0}$ & $\mathbf{7 9}$ & $\mathbf{2 3 9}$ \\
\hline Third & 1980 & 16,334 & 2,535 & 1,774 & 3,299 & 6,159 & 2,078 & 858 & 369 \\
& 1990 & 19,074 & 2,073 & 3,066 & 3,903 & 6,031 & 4,233 & 1,082 & 1,314 \\
& Change & $\mathbf{2 , 7 4 0}$ & $\mathbf{- 4 6 2}$ & $\mathbf{1 , 2 9 2}$ & $\mathbf{6 0 4}$ & $\mathbf{- 1 2 8}$ & $\mathbf{2 , 1 5 5}$ & $\mathbf{2 2 4}$ & $\mathbf{9 4 5}$ \\
\hline Fourth & 1980 & 23,672 & 7,468 & 3,614 & 6,580 & 5,027 & 2,053 & 744 & 1,814 \\
& 1990 & 25,812 & 5,929 & 5,776 & 6,671 & 5,422 & 4,640 & 1,064 & 3,689 \\
& Change & $\mathbf{2 , 1 4 0}$ & $\mathbf{- 1 , 5 3 9}$ & $\mathbf{2 , 1 6 2}$ & $\mathbf{9 1}$ & $\mathbf{3 9 5}$ & $\mathbf{2 , 5 8 7}$ & $\mathbf{3 2 0}$ & $\mathbf{1 , 8 7 5}$ \\
\hline Top & 1980 & 42,389 & 19,990 & 6,939 & 16,104 & 4,668 & 2,325 & 627 & 8,265 \\
& 1990 & 42,719 & 13,706 & 11,612 & 17,545 & 5,236 & 4,748 & 1,110 & 11,238 \\
& \multicolumn{1}{|c|}{ Change } & $\mathbf{3 3 0}$ & $\mathbf{- 6 , 2 8 4}$ & $\mathbf{4 , 6 7 3}$ & $\mathbf{1 , 4 4 1}$ & $\mathbf{5 6 8}$ & $\mathbf{2 , 4 2 3}$ & $\mathbf{4 8 3}$ & $\mathbf{2 , 9 7 3}$ \\
\hline
\end{tabular}

Real income gains in the 1990s (Table 5) were comparatively modest in all quintiles but are instructive nonetheless. Higher C/QPP benefits favoured lower-income households but the gains were significantly offset by lower GIS benefits that, by design, are reduced as other income rises. Private pensions grew faster than C/QPP in the 1990s and mainly benefited the higher quintiles.

Following Pedersen (1999), we can formalize the usual arguments concerning the redistributive impact of alternative pension designs with the so-called "natural" decomposition of Gini index of inequality as formulated by Lerman and Yitzhaki (1985). The contribution of any particular income source $\left(\mathrm{Q}_{\mathrm{k}}\right)$ to total inequality $(\mathrm{G})$ can be partitioned into three factors: the Gini coefficient for the component $\left(\mathrm{G}_{\mathrm{k}}\right)$, the share of that component in the overall income package $\left(\mathrm{S}_{\mathrm{k}}\right)$ and the correlation (see footnote) between the component and the overall income package $\left(\mathrm{R}_{\mathrm{k}}\right)$ so that: ${ }^{11}$

11 The "Gini correlation" $\left(\mathrm{R}_{\mathrm{k}}\right)$ is a hybrid of the familiar Pearsons's $\mathrm{R}$ and the Spearman rank correlation coefficient and is calculated by taking the ratio of the covariance of income component $k$ with cumulative distribution of final disposable income to the covariance of income component $k$ with the cumulative distribution of component $k$. Like the conventional correlation it takes on value between -1 and +1 and $\mathrm{R}_{\mathrm{k}}$ will be equal to 1 


$$
\mathrm{G}=\Sigma \mathrm{Q}_{\mathrm{k}}=\Sigma \mathrm{G}_{\mathrm{k}} \cdot \mathrm{S}_{\mathrm{k}} \cdot \mathrm{R}_{\mathrm{k}}
$$

which simply stated means that overall inequality is determined by inequality in the distribution of the component itself, its share in the overall income package and its covariation with the remaining income components.

The concentration of an income source by income level, called a pseudo-Gini $\left(\mathrm{G}_{\mathrm{k}}{ }^{*}\right)$, is equal to the product of the true Gini $\left(\mathrm{G}_{\mathrm{k}}\right)$ for each income component and the relative correlation $\left(\mathrm{R}_{\mathrm{k}}\right)$ of that component with total income as in:

$$
\text { (2) } \mathrm{G}_{\mathrm{k}} *=\mathrm{G}_{\mathrm{k}} \cdot \mathrm{R}_{\mathrm{k}}
$$

so that (1) can be rewritten as:

(3) $\quad \mathrm{G}=\Sigma \mathrm{Q}_{\mathrm{k}}=\Sigma \mathrm{G}_{\mathrm{k}} * \cdot \mathrm{S}_{\mathrm{k}}$

which corresponds to the intuition that total inequality is a function of the concentration of income components by income level and the component's share of total income.

The ways in which alternative pension designs might affect inequality are now easily highlighted. Since, by definition, the value of a uniform transfer such as OAS is the same across all persons, the value of Gini $\left(\mathrm{G}_{\mathrm{k}}\right)$ and hence of $\mathrm{Q}_{\mathrm{k}}$ for this component is always zero. As its share $\left(\mathrm{S}_{\mathrm{k}}\right)$ of the income package rises, inequality will fall. As Pedersen (1999:63) points out, for example, if a uniform transfer is introduced and it takes up exactly 10 percent of the new income package, then inequality will fall by 10 percent.

The Gini $\left(\mathrm{G}_{\mathrm{k}}\right)$ for an income-tested transfer (such as GIS) will be positive but it's correlation $\left(\mathrm{R}_{\mathrm{k}}\right)$ with total income is, by definition, negative (and $\mathrm{G}_{\mathrm{k}}{ }^{*}$ will be negative) so that as the share of income-tested benefits in the income package rises income inequality will fall. A progressive income tax will have a positive value for $\mathrm{G}_{\mathrm{k}}$ * but since it is a deduction from income $\mathrm{S}_{\mathrm{k}}$ (and hence $\mathrm{Q}_{\mathrm{k}}$ ) will be negative and will be inequality reducing.

Relative to OAS and GIS, rising C/QPP incomes might be expected to increase inequality since, by definition, the value of $\mathrm{G}_{\mathrm{k}}{ }^{*}$ for an earnings-related plan will be positive. The actual historical sequence (the observed trend in inequality), however, is given not by what might have occurred but by what actually occurred. Thus, so long as income sources that are growing (such as C/QPP or even private pension income) are less concentrated than the income sources they are replacing (such as employment and investment income), inequality will decline.

Table 6 shows the concentration $\left(\mathrm{G}_{\mathrm{k}}{ }^{*}\right)$ and share $\left(\mathrm{S}_{\mathrm{k}}\right)$ values in the four comparison years. The values of the concentration ratios are relatively stable over the period except for C/QPP income. Employment, private pension and investment income are highly concentrated among upperincome seniors, C/QPP has a very low (and declining) concentration ratio while OAS/GIS has a negative concentration ratio (is inversely related to total disposable income). The shares of

whenever the ranking of individuals on the particular component is identical to the ranking of individuals on total (disposable) income (see Pedersen, 1999: 220). 
income by source, in contrast, change quite substantially, dominated by the shift from employment and investment income to C/QPP and private pension income. Income taxes, highly concentrated among upper income seniors, also rose substantially from about 10 to 16 percent of total income. In short, income inequality falls over the period mainly as a result of the shift from income sources that are highly concentrated to income sources that are less concentrated, especially to C/QPP income, and by rising taxes.

Interpretation of these results hinges critically on an understanding of what the decomposition does not tell us. The values in Table 6 do not allow for causal or counterfactual ("what if") statements about what would have happened had the pattern of change been different. Rather, they simply allow us to describe history - what did happen in an accounting sense. As with all such decompositions, the natural decomposition of Gini provides a purely static analysis, ignoring behavioral responses or any possible dependency of one income component on the size and distribution of another. Moreover, the key to understanding the decomposition is its "simultaneity" - every term in the decomposition depends on every other term since by definition the share of one component can rise only if the share of another component declines. ${ }^{12}$ During the 1980s, total inequality declined from .325 to .274 (a change of -.051). The changing mix among employment, investment private pension and C/QPP income accounts for about 53 percent of the change (-.027), rising taxes for 37 percent (-.019) and OAS/GIS for remaining 10 percent (-.005). ${ }^{13}$ The comparatively modest contribution of changes in OAS/GIS benefits (the largest source of rising income in the lowest quintile) should be interpreted in light of the fact that had increases in OAS/GIS not kept pace with the general rise in old age incomes (had the share declined) income inequality would have fallen substantially less over the decade. ${ }^{14}$ The conclusion is not that gains in OAS/GIS benefits for low-income seniors were unimportant; rather total change in inequality was dominated by the much larger shifts from employment to pension income and by rising taxes (including OAS/GIS clawbacks) for higher income seniors.

12 Moreover, the value of $\mathrm{G}^{*}$ is not independent of $\mathrm{S}$ since $\mathrm{S}$ and $\mathrm{R}$ are correlated: as the share of a component rises its influence on Gini also rises as it comes to dominate the overall income distribution.

13 This decomposition of change is calculated by summing across change in the values of $\mathrm{Q}$ for the relevant components. The largest change (as indicated by the value of $\mathrm{Q}$ ) is the substantial decline in the contribution of employment income to total inequality (-. 070), reflecting the large decline in the share of employment income in the total income package. By definition, however, the share of employment income can only fall if the shares of other income sources rise. In this period, the shift is dominated by the rising shares of C/QPP and private pension income and their joint contribution to inequality rises by .047 (.035 for private pensions +.012 for C/QPP). The net change after including a modest change (-.003) in the contribution of investment income, is -.027

14 Since Gini is especially sensitive to changes in the middle of the income distribution the results are indexspecific. An index sensitive to changes in the lower tail of the distribution would undoubtedly show a greater sensitivity to the changing distribution of OAS/GIS income. 
Table 5: Mean Adjusted Income by Source and Income Quintile, Population 65+, 1991-95

\begin{tabular}{|lc|c|c|c|c|c|c|c|c|}
\hline QUINTILE & $\begin{array}{c}\text { Disposable } \\
\text { Income } \\
\text { (minus taxes) }\end{array}$ & $\begin{array}{c}\text { Employment } \\
\text { Income }\end{array}$ & $\begin{array}{c}\text { Private } \\
\text { Pensions }\end{array}$ & $\begin{array}{l}\text { Other } \\
\text { Market } \\
\text { Income }\end{array}$ & $\begin{array}{c}\text { OAS/ } \\
\text { GIS }\end{array}$ & $\begin{array}{c}\text { CPP/ } \\
\text { QPP }\end{array}$ & $\begin{array}{c}\text { Other } \\
\text { Transfers }\end{array}$ & Taxes \\
\hline Bottom & 1991 & 11,772 & 370 & 224 & 565 & 8,295 & 1,504 & 959 & 145 \\
& 1995 & 12,283 & 275 & 352 & 541 & 7,886 & 2,482 & 928 & 181 \\
& Change & $\mathbf{5 1 1}$ & $\mathbf{- 9 5}$ & $\mathbf{1 2 8}$ & $\mathbf{- 2 4}$ & $\mathbf{- 4 0 9}$ & $\mathbf{9 7 8}$ & $\mathbf{- 3 1}$ & $\mathbf{3 6}$ \\
\hline Second & 1991 & 15,188 & 452 & 996 & 1,955 & 7,686 & 3,452 & 935 & 289 \\
& 1995 & 15,546 & 480 & 1,508 & 1,397 & 7,158 & 4,610 & 800 & 406 \\
& Change & $\mathbf{3 5 8}$ & $\mathbf{2 8}$ & $\mathbf{5 1 2}$ & $\mathbf{- 5 5 8}$ & $\mathbf{- 5 2 8}$ & $\mathbf{1 , 1 5 8}$ & $\mathbf{- 1 3 5}$ & $\mathbf{1 1 7}$ \\
\hline Third & 1991 & 18,288 & 1,695 & 2,871 & 3,173 & 6,308 & 4,199 & 1,294 & 1,250 \\
& 1995 & 19,329 & 2,174 & 4,226 & 2,456 & 5,875 & 4,990 & 1,154 & 1,546 \\
& Change & $\mathbf{1 , 0 4 1}$ & $\mathbf{4 7 9}$ & $\mathbf{1 , 3 5 5}$ & $\mathbf{- 7 1 7}$ & $\mathbf{- 4 3 3}$ & $\mathbf{7 9 1}$ & $\mathbf{- 1 4 0}$ & $\mathbf{2 9 6}$ \\
\hline Fourth & 1991 & 24,581 & 5,523 & 5,748 & 5,674 & 5,437 & 4,471 & 1,166 & 3,438 \\
& 1995 & 25,326 & 5,199 & 7,676 & 4,202 & 5,494 & 5,187 & 1,268 & 3,701 \\
& Change & $\mathbf{7 4 5}$ & $\mathbf{- 3 2 4}$ & $\mathbf{1 , 9 2 8}$ & $\mathbf{- 1 , 4 7 2}$ & $\mathbf{5 7}$ & $\mathbf{7 1 6}$ & $\mathbf{1 0 2}$ & $\mathbf{2 6 3}$ \\
\hline Top & 1991 & 41,919 & 17,393 & 11,295 & 14,544 & 5,020 & 4,582 & 1,051 & 11,966 \\
& 1995 & 42,934 & 14,782 & 14,522 & 13,923 & 5,248 & 5,358 & 1,350 & 12,249 \\
& Change & $\mathbf{1 , 0 1 5}$ & $\mathbf{- 2 , 6 1 1}$ & $\mathbf{3 , 2 2 7}$ & $\mathbf{- 6 2 1}$ & $\mathbf{2 2 8}$ & $\mathbf{7 7 6}$ & $\mathbf{2 9 9}$ & $\mathbf{2 8 3}$ \\
\hline
\end{tabular}

Table 6: Concentration of Adjusted Income and Income Shares by Source, Population 65+, 1980-95

\begin{tabular}{|l|cc|cc|}
\hline \multicolumn{5}{|c|}{ Concentration (G*) } \\
\hline & $\mathbf{1 9 8 0}$ & $\mathbf{1 9 9 0}$ & $\mathbf{1 9 9 1}$ & $\mathbf{1 9 9 5}$ \\
\hline Employment & 0.650 & 0.620 & 0.672 & 0.629 \\
Investment & 0.552 & 0.552 & 0.538 & 0.580 \\
Private Pension & 0.516 & 0.533 & 0.533 & 0.518 \\
C/QPP & 0.192 & 0.170 & 0.159 & 0.117 \\
OAS/GIS & -0.079 & -0.107 & -0.109 & -0.088 \\
Other Transfers & -0.039 & 0.036 & 0.024 & 0.086 \\
Taxes & 0.757 & 0.655 & 0.682 & 0.662 \\
\hline \multicolumn{5}{|c|}{ Shares (S) } \\
\hline \multicolumn{5}{|c|}{$\mathbf{( 1 9 9 1}$} \\
\hline Employment & $\mathbf{1 9 8 0}$ & $\mathbf{1 9 9 0}$ & $\mathbf{1 9 9 1}$ & $\mathbf{1 9 9 5}$ \\
Investment & $29.5 \%$ & $19.5 \%$ & $22.7 \%$ \\
Private Pension & $27.4 \%$ & $26.8 \%$ & $22.9 \%$ & $19.8 \%$ \\
C/QPP & $12.8 \%$ & $18.9 \%$ & $19.0 \%$ & $24 \%$ \\
OAS/GIS & $8.2 \%$ & $16.3 \%$ & $16.5 \%$ & $19.6 \%$ \\
Other Transfers & $28.7 \%$ & $28.7 \%$ & $29.3 \%$ & $27.4 \%$ \\
Taxes & $3.7 \%$ & $4.5 \%$ & $4.8 \%$ & $4.8 \%$ \\
\hline \multicolumn{1}{|c|}{ Gini $=$} & $-10.2 \%$ & $-14.7 \%$ & $-15.3 \%$ & $-15.7 \%$ \\
\hline
\end{tabular}


Table 7: Elasticities of Gini Inequality With Respect to Proportionate Changes in Specific Income Sources, 1980-1990

\begin{tabular}{|l|c|c|c|c|c|c|c|}
\hline & Employment & $\begin{array}{c}\text { Private } \\
\text { Pensions }\end{array}$ & Investment & OAS/GIS & CPP/QPP & $\begin{array}{c}\text { Other } \\
\text { Transfers }\end{array}$ & Taxes \\
\hline Elasticities, 1980 & 0.298 & 0.076 & 0.194 & -0.357 & -0.033 & -0.041 & -0.136 \\
\hline Elasticities, 1990 & 0.249 & 0.182 & 0.276 & -0.400 & -0.061 & -0.039 & -0.206 \\
\hline
\end{tabular}

Because of the interdependence among terms in the decomposition, the decomposition of Gini in Table 6 does not allow for quantitative assessments of how much change in Gini would occur if the pattern of change was different from that actually observed (e.g. "what if" C/QPP benefits increased more and private pensions increased less). Lerman and Yitzhaki (1985), however, have shown how modification to the formula can give the elasticities of the overall Gini with respect to small proportionate changes in component shares, changes that leave the value of $\mathrm{G}^{*}$ for the component as well as the overall ranking of income recipients unchanged (see Pedersen, 1999, for a discussion).

The elasticities reported in Table 7 confirm the intuition about the relative distributive impact of the various income sources on total inequality. Small proportional increases in private income sources tend to increase inequality while small proportional increases from all public income sources, including C/QPP, tend to reduce inequality. The changes in elasticities observed over the decade reflect the changes in the relative contribution of each factor to total inequality $\left(\mathrm{Q}_{\mathrm{k}} / \mathrm{G}\right)$. Thus, the (positive) factor elasticity for private pensions and the (negative) elasticity for C/QPP incomes (and taxes) rise because they account for a larger share of total inequality in 1990 than in 1980.

Finally, it is instructive to consider the distribution/concentration of transfers and taxes by source in the mid-nineties. In combination, the distribution of all transfers in 1995 functioned approximately like a universal flat benefit system. C/QPP benefits rise moderately with income level $\left(\mathrm{G}^{*}=.117\right)$ offset by OAS/GIS benefits that decline slightly with total income $\left(\mathrm{G}^{*}=-.088\right)$. The result is a concentration ratio for all transfers before taxes that is close to zero $\left(\mathrm{G}^{*}=.006\right)$. In effect, by the mid-nineties, the overall transfer system functioned little differently from the initial design of the flat rate Old Age Security benefit implemented in 1951, albeit at a much higher level. When combined with taxes, of course, the net result corresponds to a tax-transfer system that is progressive $\left(\mathrm{G}^{*}=-.278\right)$.

Table 8: Distribution and Concentration of Adjusted Transfers and Taxes by Source, Population 65+, 1995

\begin{tabular}{|l|c|c|c|c|c|c|}
\hline \multicolumn{1}{|c|}{ Quintile } & C/QPP & OAS/GIS & $\begin{array}{c}\text { Other } \\
\text { Transfers }\end{array}$ & Taxes & $\begin{array}{c}\text { Total Transfers } \\
\text { (pre-tax) }\end{array}$ & $\begin{array}{c}\text { Net Transfers } \\
\text { (post-tax) }\end{array}$ \\
\hline Bottom & 2,482 & 7,886 & 928 & 181 & 11,296 & 11,115 \\
Second & 4,610 & 7,158 & 800 & 406 & 12,568 & 12,162 \\
Third & 4,990 & 5,875 & 1,154 & 1,546 & 12,019 & 10,473 \\
Fourth & 5,187 & 5,494 & 1,268 & 3,701 & 11,949 & 8,248 \\
Top & 5,358 & 5,248 & 1,350 & 12,249 & 11,956 & -293 \\
\multicolumn{1}{|c|}{$\mathrm{G}^{*}=$} & 0.117 & -0.088 & 0.063 & 0.662 & & .006 \\
\hline
\end{tabular}




\section{Low (and High) Income Trends}

Rising incomes and declining low-income rates among the elderly have been a general trend in most OECD countries since the end of the 1960s, reversing the trend of the previous two decades. Following the Second World War, the economic status of the elderly fell relative to the working-age population for several reasons. On the one hand, the rapid postwar decline in labour force participation among men over 65 took place in a context where old age pension systems were relatively underdeveloped. And, on the other, working-age families were enjoying unprecedented increases in wages and earnings. In effect, the elderly missed the rising tide of postwar expansion. By the mid-1960s, old age poverty was everywhere a major concern and old age pensions underwent a major round of legislative reform (Myles, 1989). The results of reform were evident sooner in some countries than in others. In the mid-seventies, low-income rates among Canadian seniors were well above those of their U.S. counterparts (Myles and Quadagno, 1994; Smeeding and Sullivan, 1998).

Charts 4 and 5 show trends in low-income among all Canadian seniors and among unattached elderly women since 1980 with four different series (based on four different cut-offs) routinely published by Statistics Canada. Low-Income Measures (LIMs) are purely relative measures calculated by estimating the percent of the population in families with less than 50 percent of the median income for all families, one based on pre-tax income (the LIM) and the other based on after-tax income (the LIM-IAT). The latter cut-off (LIM-IAT) corresponds to the standard used in the international comparative studies noted in the introduction. And it is evident that by this criterion, low-income among seniors had virtually disappeared in Canada by the mid-nineties.

Statistics Canada's Low-Income Cut-Offs (LICOs) are the more familiar standard in Canadian discussions of low-income levels. As with the LIMs, two series are calculated, before (the LICO) and after (the LICO-IAT) taxes. LICOs are calculated by estimating the percentage of income the average family spends on necessities (food, clothing and shelter). Since expenditures on necessities declines as income rises, families who expend significantly more than average (+20 percent) are deemed to be in low-income. The LICOs are rebased from time to time to introduce a relative component by taking account of changes in real living standards. Here, however, we use the 1992 base throughout, effectively treating the LICOs as "fixed" measures of low-income. ${ }^{15}$

The choice of low-income cut-offs remains controversial in Canadian policy circles and I shall not attempt to adjudicate among them here except to note that the temptation to become exercised over the radically different low-income rates produced by the different standards is probably worth avoiding. Low-income-cut-offs are useful for describing trends (or differences among populations) but by themselves point estimates of low-income rates at a single point in time or a single population are not particularly instructive for the elderly population. Since most low-income seniors are clustered within a very narrow income band, small differences in the choice of cut-offs produce very large differences in the percent who fall below the cut-off. ${ }^{16}$

15 The LICO is fixed at the 1996 levels, based on the 1992 revisions. Earnings are then computed in 1996 constant dollars, and the cut-offs applied to these earnings.

16 In 1996, the average LICO cut-offs were approximately 56 percent of the median pre-tax income of all families and the LICO-IAT cut-offs about 55 percent of median post-tax income. In effect, shifting from the pre-tax to the 


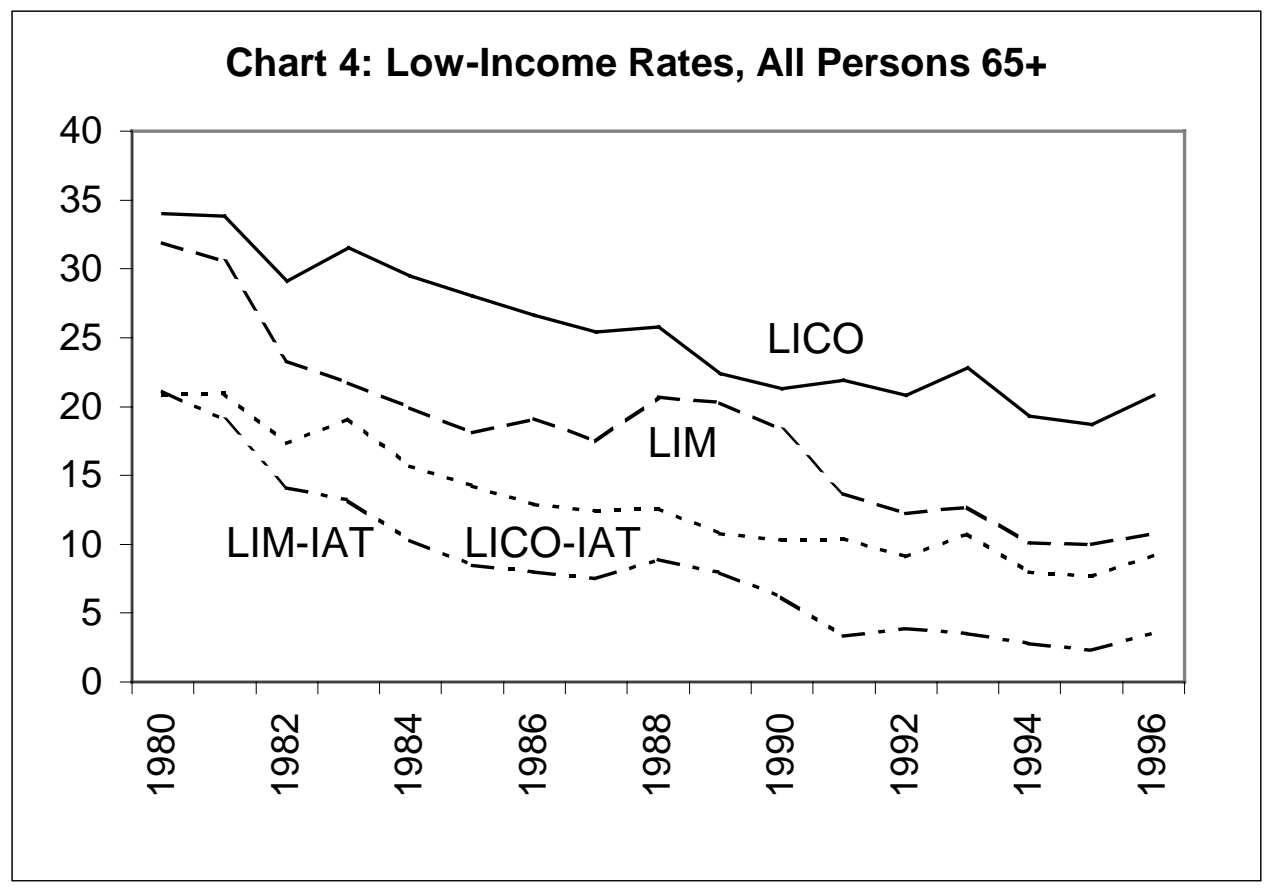

All four measures show the same striking downward trend among both the elderly population as a whole and among unattached elderly women. Not surprisingly, given the changes in taxation over the period, declines in the after-tax low-income rates are much sharper than declines in the pre-tax rates. Trends in the LICO and the LICO-IAT show changes measured in real (constant 1996) dollars while trends in the LIM and LIM-IAT are indicative of changes in the position of the elderly relative to the entire population. LIM-based measures tend to be counter-cyclical since the incomes of the elderly rise more slowly than those of younger families during periods of economic expansion (when labour market earnings are rising) and conversely decline much less than those of younger families during recessions, when earnings are falling. The main conclusion, however, is simply that for the period as a whole, low-income rates fell and fell substantially irrespective of the choice of cut-off.

The depth of low-income among seniors below the cut-offs also fell over the period. Between 1980 and 1996, for example, the average low-income income gap (the income, it would take to lift low-income seniors above the low-income cut-off expressed as a $\%$ of the low-income cutoff) among low-income seniors fell from $26 \%$ to $19 \%$ based on the LICO and from $22 \%$ to $17 \%$ based on the LICO-IAT. In short, the real living standards of seniors below the low-income cutoff were also rising.

post-tax distribution cuts the low-income rate of seniors in half. Moving from the LICO-IAT (55 percent of the median) to the LIM-IAT (50 percent of the median) cuts the low-income rate in half again. 


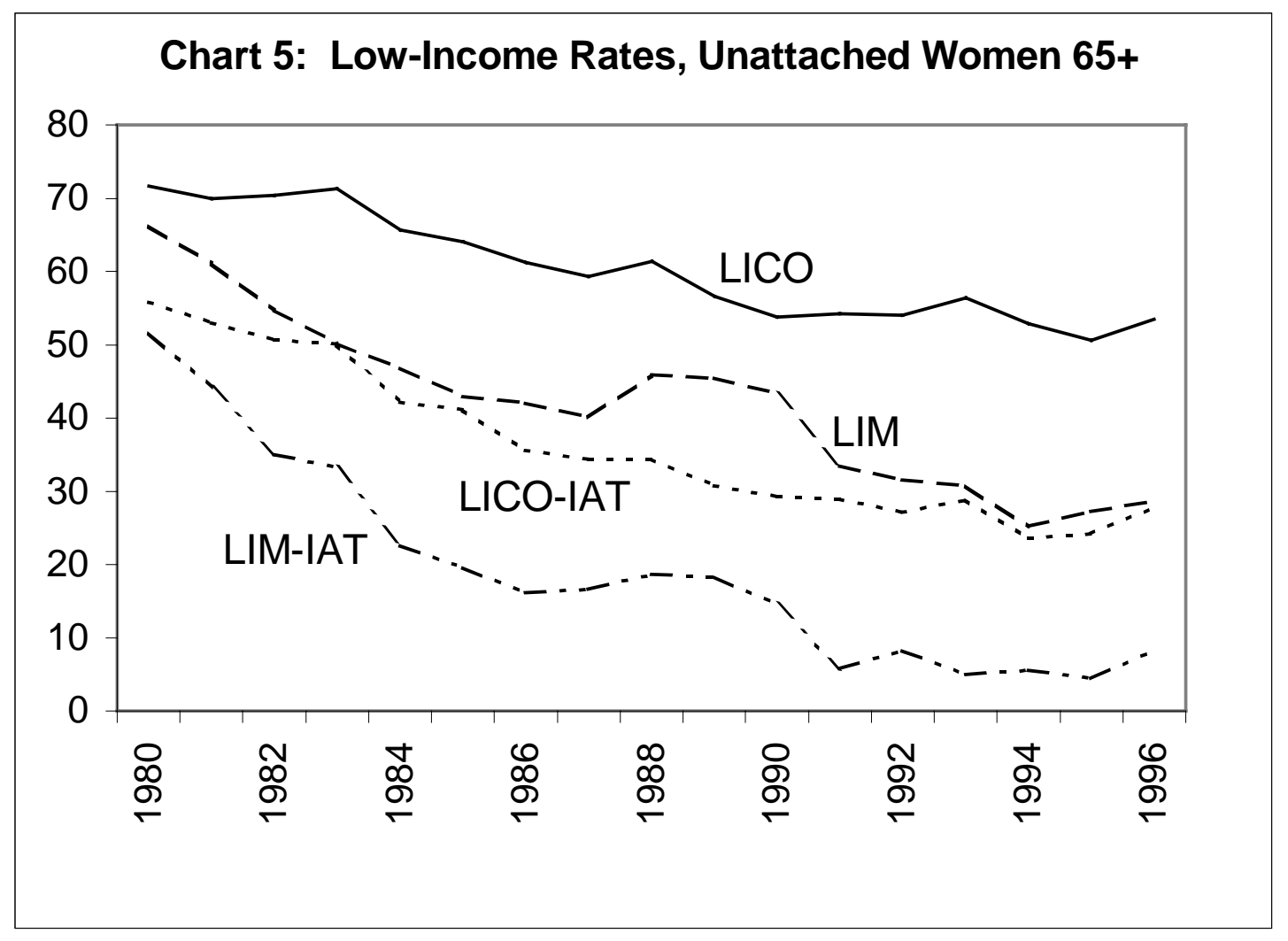

Given the design of the Canadian old age security system it is entirely possible, of course, that low-income trends are the product of the GIS supplemental income level. Canada, unlike most nations, has a remarkably flexible income security system due to the Guaranteed Income Supplement (GIS) introduced in 1966. GIS is an income-tested program that in effect functions as a negative income tax (NIT) or, as the name indicates, a guaranteed income. In theory, at least, it may be that the guarantee level is such that all seniors are huddled in a highly-concentrated income band just above the low-income cut-offs. In that case, declining low-income rates could be an artifact of pushing a large number of seniors who might otherwise be a few dollars below the cut-off to a few dollars above it.

Table 9: Income Levels Relative to Low-Income Cut-Offs, Population 65+

\begin{tabular}{|c|c|c|c|c|}
\hline \multicolumn{5}{|c|}{ Income Relative to LICO } \\
\hline & 1980 & 1986 & 1990 & 1996 \\
\hline$>1.0$ & 33.4 & 26.6 & 21.3 & 20.8 \\
\hline $1.0-1.5$ & 25.4 & 30.9 & 28.0 & 29.4 \\
\hline $1.5-3.0$ & 29.9 & 31.9 & 36.4 & 35.2 \\
\hline $3.0+$ & 11.3 & 10.6 & 14.3 & 14.6 \\
\hline \multicolumn{5}{|c|}{ Income Relative to LICO-IAT } \\
\hline & 1980 & 1986 & 1990 & 1996 \\
\hline$>1.0$ & 20.1 & 12.9 & 10.3 & 9.6 \\
\hline $1.0-1.5$ & 26.0 & 29.9 & 25.1 & 26.8 \\
\hline $1.5-3.0$ & 38.2 & 44.3 & 47.9 & 48.3 \\
\hline $3.0+$ & 15.8 & 12.8 & 16.7 & 15.3 \\
\hline
\end{tabular}


Even when measured against the most generous cut-off (the LICO), however, this conclusion finds little support (Table 9). Declines in the LICO rate in the first half of the 1980s were achieved in this way. GIS benefits were raised in 1984 and by 1986, the LICO low-income rate fell to about $27 \%$ from $33 \%$ in 1980 with virtually all of the change a result of an increase in the share of seniors just above the LICO. However over the entire period, the LICO rate declined from 33.4 to 20.8 percent and the LICO-IAT rate from 20.1 to 9.6 percent. About three-quarters of the change reflected in the LICO rate and all of the change in the LICO-IAT rate was the result of an increase in the percent of seniors whose incomes were at least 1.5 times their respective cut-offs.

\section{How Have Seniors Fared Relative to the Population as a Whole?}

Until now, we have focused our attention on trends within the elderly population. For many purposes, however, we would also like to know how well seniors have fared relative to the Canadian population as a whole. To address this issue, Table 10 shows the changing distribution of the elderly among income quintiles calculated for the entire population. In 1980, almost 40 percent of all elderly persons were in the bottom quintile, twice the rate of the population as a whole. By 1995, just over 17 percent of the elderly were in the bottom quintile, somewhat below the level (i.e. 20 percent) of the entire population. Among unattached elderly women, the percentage in the bottom (population) quintile fell from 70 to 42 percent. Approximately 80 percent of the total shift out of the bottom quintile reflected movement into the second and third quintiles for the elderly population as whole and into the second quintile among unattached elderly women. There was very little increase in the proportion of seniors in the top two quintiles, however. In short, the elderly moved up significantly over the period but virtually all of the movement was from the bottom to the middle of the income distribution.

Table 10: The Distribution of the Elderly by Population Income Quintile, 1980-95

\begin{tabular}{|c|c|c|c|c|c|}
\hline \multicolumn{6}{|c|}{ Population 65+ } \\
\hline & & 1980 & 1990 & 1995 & Change, 1980-95 \\
\hline \multirow[t]{6}{*}{ Quintile } & Bottom & 39.7 & 25.2 & 17.5 & -22.2 \\
\hline & $2^{\text {nd }}$ & 22.1 & 29.7 & 32.5 & 10.5 \\
\hline & $3^{\text {rd }}$ & 12.2 & 16.2 & 20.0 & 7.8 \\
\hline & $4^{\text {th }}$ & 13.3 & 14.9 & 16.0 & 2.7 \\
\hline & Тор & 12.8 & 13.9 & 14.0 & 1.2 \\
\hline & tal: all quintiles & 100 & 100 & 100 & \\
\hline \multicolumn{6}{|c|}{ Unattached Women, 65+ } \\
\hline & & 1980 & 1990 & 1995 & Change, 1980-95 \\
\hline \multirow[t]{6}{*}{ Quintile } & Bottom & 69.5 & 53.4 & 42.0 & -27.5 \\
\hline & & 13.7 & 26.1 & 35.4 & 21.7 \\
\hline & $3^{\text {rd }}$ & 5.6 & 9.1 & 11.1 & 5.5 \\
\hline & $4^{\text {th }}$ & 5.7 & 6.4 & 7.5 & 1.9 \\
\hline & Top & 5.6 & 5.0 & 4.0 & -1.5 \\
\hline & tal: all quintiles & 100 & 100 & 100 & \\
\hline
\end{tabular}




\section{Conclusion}

By standards of OECD countries, Canadian public expenditures on income security for seniors are quite modest and are projected to peak at levels well below those anticipated in most other Western nations in the next century (Organization for Economic Cooperation and Development, 1997). At the same time, low-income rates among Canadian seniors have been brought down to levels that are enviable by international standards. ${ }^{17}$ Unlike the United States, where declining poverty rates among seniors have taken place against a background of rising inequality, a significant element in the rising living standards at the lower end of the Canadian old age income distribution is a product of redistribution that has taken place within the elderly population. Moreover, the fact that there has been little movement of Canadian seniors into the upper levels of the Canadian income distribution no doubt helps to account for the very different policy climate surrounding policy debates in the two countries. As Cook and her colleagues (Cook, Marshall, Marshall, and Kaufman, 1994) have documented, the political rhetoric of "intergenerational equity" has played a negligible role in Canadian policy circles (or academic research) relative to the United States.

As stock-market advisors warn, however, projecting past trends into the future is a bit like driving while staring into the rear-view mirror. Drawing policy conclusions from inspecting the past, including the recent past, is an equally hazardous exercise. The relative status of the elderly in any particular period is a result of what might be called generational overlap. The relative low-income of the elderly in the 1960s reflected the fact that they were born too soon to reap the benefits of rising wages and pension benefits that came to younger cohorts with the postwar boom. They carried the economic scars of the depression years into old age at the very moment when working-age families were experiencing the largest gains in real incomes seen before or since. The relative gains in incomes of the elderly since 1980 are, one the one hand a product of their own biographies (the rising wages and better pensions that followed the war) and, on the other, the relative stagnation in wages and incomes of working-age families in more recent decades. Birth, as Easterlin (1980) argues, is fortune.

Declining inequality in the 1980s was the product of a large decline in earned income and a shift toward pension and especially C/QPP income. In short, a source of income that is highly concentrated (earnings) was falling, offset by a rapid increase in an income source with very low concentration $(\mathrm{C} / \mathrm{QPP}$ income). This was a period of transition that will not be repeated. The fall in earned income has a lower limit and the C/QPP is near maturity. Trends in the next decade are more likely to be dominated by continued maturation of employer pensions (RPPs) and personal retirement accounts (RRSPs). ${ }^{18}$ As these elements of the retirement income system are more highly concentrated among high-wage earners, the trend toward declining inequality among Canadian seniors is not likely to continue indefinitely. Income levels among the elderly are obviously open to many influences, including future public pension policy including indexing provisions, changing economic conditions, and trends in private pensions and RRSP usage.

17 See for example Hauser (1997) for this assessment of Canada within an international context.

18 Recent declines in occupational pension coverage for younger men (Morissette and Drolet, 1998) may also impact future retirement incomes. 


\section{References}

Atkinson, A.B., L. Rainwater, and T. Smeeding, (1995). Income Distribution in OECD Countries: Evidence from the Luxembourg Income Study. Paris: OECD.

Blinder, A. (1983). Private Pensions and Public Pensions: Theory and Fact. Ann Arbor: University of Michigan, Department of Economics.

Burkhauser, R., T. Smeeding, and J. Merz, (1996). "Relative Inequality and Poverty in Germany and the United States Using Alternative Equivalence Scales". Review of Income and Wealth, 42(4), 381-400.

Cook, F., V. Marshall, J.G. Marshall, and J. Kaufman, (1994). "The Salience of Intergenerational Equity in Canada and the United States". In T. Marmor, T. Smeeding, and V. Greene (Eds.), Economic Security and Intergenerational Justice (pp. 91-129). Washington, D.C.: The Urban Institute.

Diamond, P. and J. Hausman, (1984). "Individual Retirement and Savings Behavior". Journal of Public Economics, 23, 81-114.

Easterlin, R. (1980). Birth and Fortune: The Impact of Numbers on Personal Welfare. New York: Basic Books.

Gower, D. 1998. "Income Transition Upon Retirement". Perspectives on Labour and Income, Winter, 18-23, Catalogue No. 75-001-XPE, Ottawa: Statistics Canada.

Hauser, R. (1997). Adequacy and poverty among the retired. Paris: Organization for Economic Cooperation and Development.

Kangas, O. (1995). "Attitudes on Means-tested Benefits in Finland". Acta Sociologica 38:299310.

Korpi, W. and J. Palme, (1998). "The Paradox of Redistribution and Strategies of Inequality: Welfare State Institutions, Inequality, and Poverty in the Western Countries". American Sociological Review, 63(Oct.), 661-687.

Le Grand, J. (1982). The Strategy of Equality. Redistribution and the Social Services. London: Geroge Allen and Unwin.

Lerman, R. and S. Yitzhaki, (1985). "Income Inequality Effects by Income Source: A New Approach and Applications to the United States". The Review of Economics and Statistics, $67,151-156$.

Mitchell, D., A. Harding, and F. Gruen, (1994). "Targeting Welfare". The Economic Record, 70, 315-340. 
Morissette, R. and M. Drolet, (1998). The Evolution of Pension Coverage of Young and Older Workers . Research Paper No. 138. Analytical Studies Branch. Ottawa: Statistics Canada.

Myles, J. (1989). Old Age in the Welfare State: The Political Economy of Public Pensions. (Rev. ed.). Lawrence, Kansas: University Press of Kansas.

Myles, J. and P. Pierson, (In Press). "The Comparative Political Economy of Pension Reform". In P. Pierson (ed.), The New Politics of the Welfare State. New York: Oxford University Press.

Myles, J. and J. Quadagno, (1994). "The Politics of Income Security for the Elderly in Canada and the United States: Explaining the Difference". In T. Marmor and T. Smeeding (eds.), Economic Security for the Elderly: North American Perspectives. Washington, D.C.: The Urban Institute.

Oja, G. and R. Love, (1988). Pensions and Incomes of the Elderly in Canada, 1971-1985. Catalogue No. 13-588. Ottawa: Statistics Canada.

Organization for Economic Cooperation and Development. (1997). Aging in OECD Countries. Paris: OECD.

Pedersen, A.W. (1999). The Taming of Inequality in Retirement: A Comparative Study of Pension Policy Outcomes. Unpublished Doctoral Dissertation, European University Institute, Florence.

Quadagno, J. (1989). "Generational Equity and the Politics of the Welfare State". Politics and Society, 17, 353-76.

Smeeding, T. and D. Sullivan, (1998). Generations and the Distribution of Economic WellBeing: A Cross-National View: Luxembourg Income Study, Working Paper Series, No. 173.

Smeeding, T., B. Torrey, and R., Martin. (1986). The Economic Status of the Young and Old in Six Countries. Luxembourg: LIS-CEPS Working Paper \#8.

Titmuss, R. (1955). "Pension Systems and Population Change". Political Quarterly, 26, 152-166.

Wolfson, M. and B. Murphy, (1994). "Kinder and Gentler: A Comparative Analysis of Incomes of the Elderly in Canada and the United States". In T. Marmor, T. Smeeding, and V. Greene (eds.), Economic Security and Intergenerational Justice. Washington D.C.: Urban Institute.

Wolfson, M.C. and J.M. Evans, (1990). Statistics Canada's Low-Income Cut-Offs: Methodological Concerns and Possibilities. Discussion paper. Analytical Studies Branch, Ottawa: Statistics Canada. 